\title{
LATVIA AS A TOURISM DESTINATION FOR GERMAN TOURISTS
}

\author{
Benjamin BLATT \\ Worms University of Applied Sciences, Worms, Germany \\ e-mail: Benjamin.Blatt1111@gmx.de,phone: +4915754282751
}

\begin{abstract}
The German source market offers a high potential for the Latvian tourism industry. This paper provides an analysis of the German outgoing tourism which allows evaluating how good the Latvian tourism market can satisfy the needs of the German outgoing tourists. This research study assesses the conformity between the needs of German travellers and the Latvian tourism offers.

The methods used in this research study are as follows: evaluation and analysis of surveys, content analysis, graphical analysis and synthesis, logical and abstract constructive methods, reference methods.
\end{abstract}

Key words: tourism development, tourists' behaviour

JEL code: $R 110, M 390$

\section{Introduction}

Latvia is a unique tourism country because of its natural and cultural diversity and its people. Due to its geographical location Latvia forms the link between East and West. Latvia spans $500 \mathrm{~km}$ along the Baltic Sea coast and half of the territory of Latvia is covered with untouched, natural forests. The climate in Latvia is characterized by its four seasons. (18)

Latvia offers various types of tourism such as beach holiday or spa resorts by the Baltic Sea in the summer, nature holidays or the city tours in the capital of Latvia, Riga. Therefore Latvia constitutes a possible tourism destination for the German tourists. Holiday travels and shortterm travels can be attractive for the German tourists. The German tourist market bears a high potential for the development of Latvian tourism industry. In 2013 Latvia received 123,400 overnight travellers from Germany. (5)

The aim of this research study is to analyse the opportunities of Latvian tourism offers and their capacities to promote the flow of tourists from Germany. To achieve this aim, several objectives are defined:

- To analyse german outbound tourism and tourists' behaviour

- To explore expectations of German tourists in 2015 and tourism trends in Germany

- $\quad$ To determine the target groups for the Latvian tourism industry

Hypothesis of the research: organized and all-inclusive roundtrips in Latvia with the focus on history, culture, nature, or health and medical 
tourism are the most suitable tourism products of the Latvian tourism market offered to the German tourists.

This research study offers an analysis of the German outbound tourism to better understand the behaviour of German travellers. The analysed factors are as follows: the number and the types of travels, the purposes of travels, the most popular destinations, expenditures, transportation, the duration of a visit as well as the type of accommodation.

The main question is: Do the offers of Latvian tourism market suit the German tourists?

The methods used in this research study are as follows: evaluation and analysis of surveys, content analysis, graphical analysis and synthesis, logical and constructive methods, reference methods.

\section{Analysis of the holiday outbound tourism in Germany}

\subsection{Holiday Travels and Short Travels}

Differences between holiday travels and short-term travels lie in their duration. A holiday travel is a travel of at least five days, in its turn, a short-term holiday is a holiday lasting less than five days.

In 2014 the number of holiday travels was 70.3 million, 54.6 million of which were the German holiday travellers. (10)

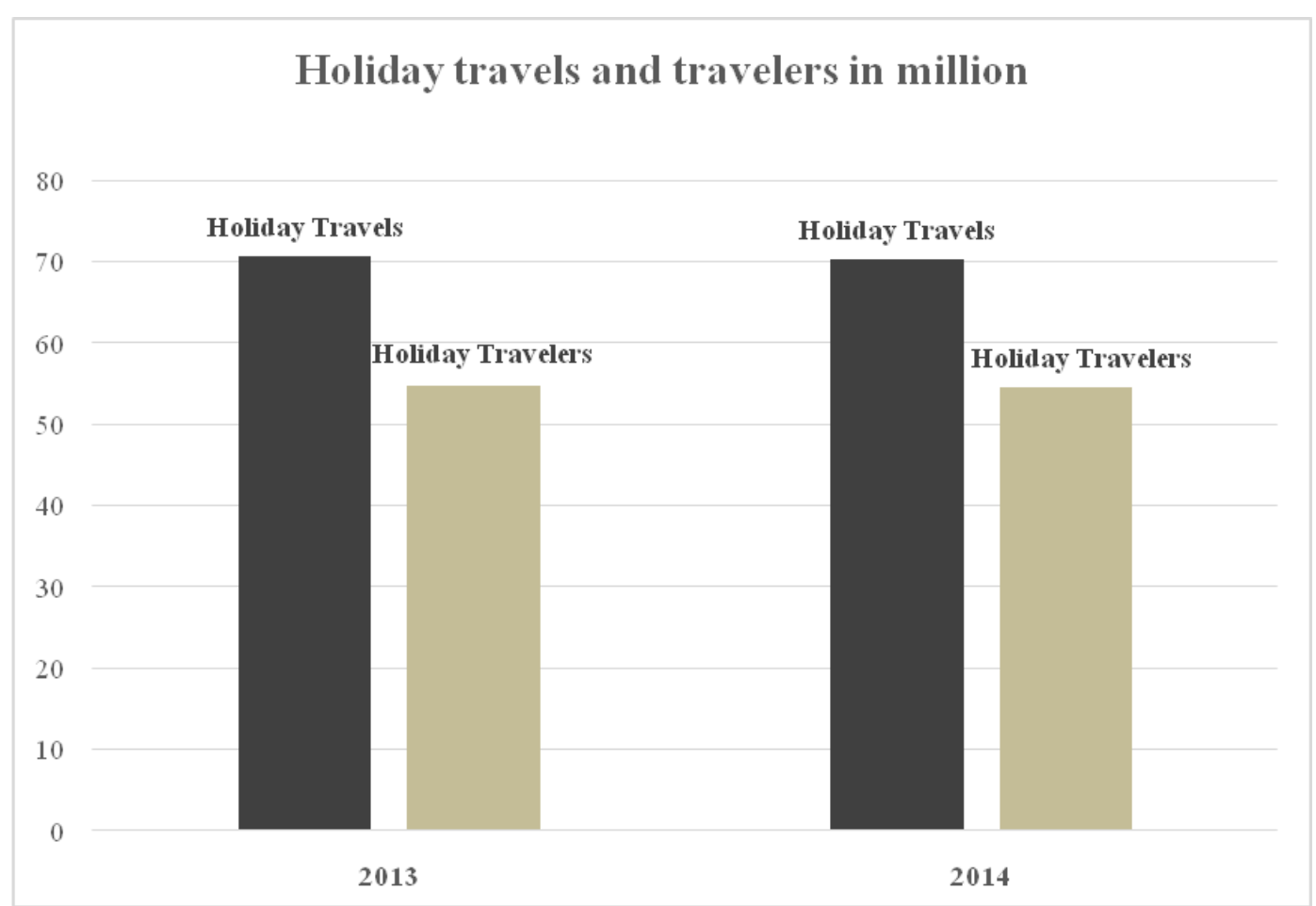

Fig. 1 Holiday travels and the number of travellers in million (Germany, 2014)

(Source: Forschungsgemeinschaft Urlaub und Reisen e.V., 2015) 
Comparing these numbers with the figures of 2013, you can note certain stability at a high level. In 2013, 70.7 million holiday travels were made by 54.8 million travellers. The figures of 2013 reflect the highest amount of German travellers in history. (10)

These numbers are equivalent to a travel intensity of $77.4 \%$. This figure reflects the percentage of the population which went on at least one holiday travel for at least five days in 2014. (10)

The frequency of travel in 2014 was 1.29 , it shows the average number of travels per person. (10)

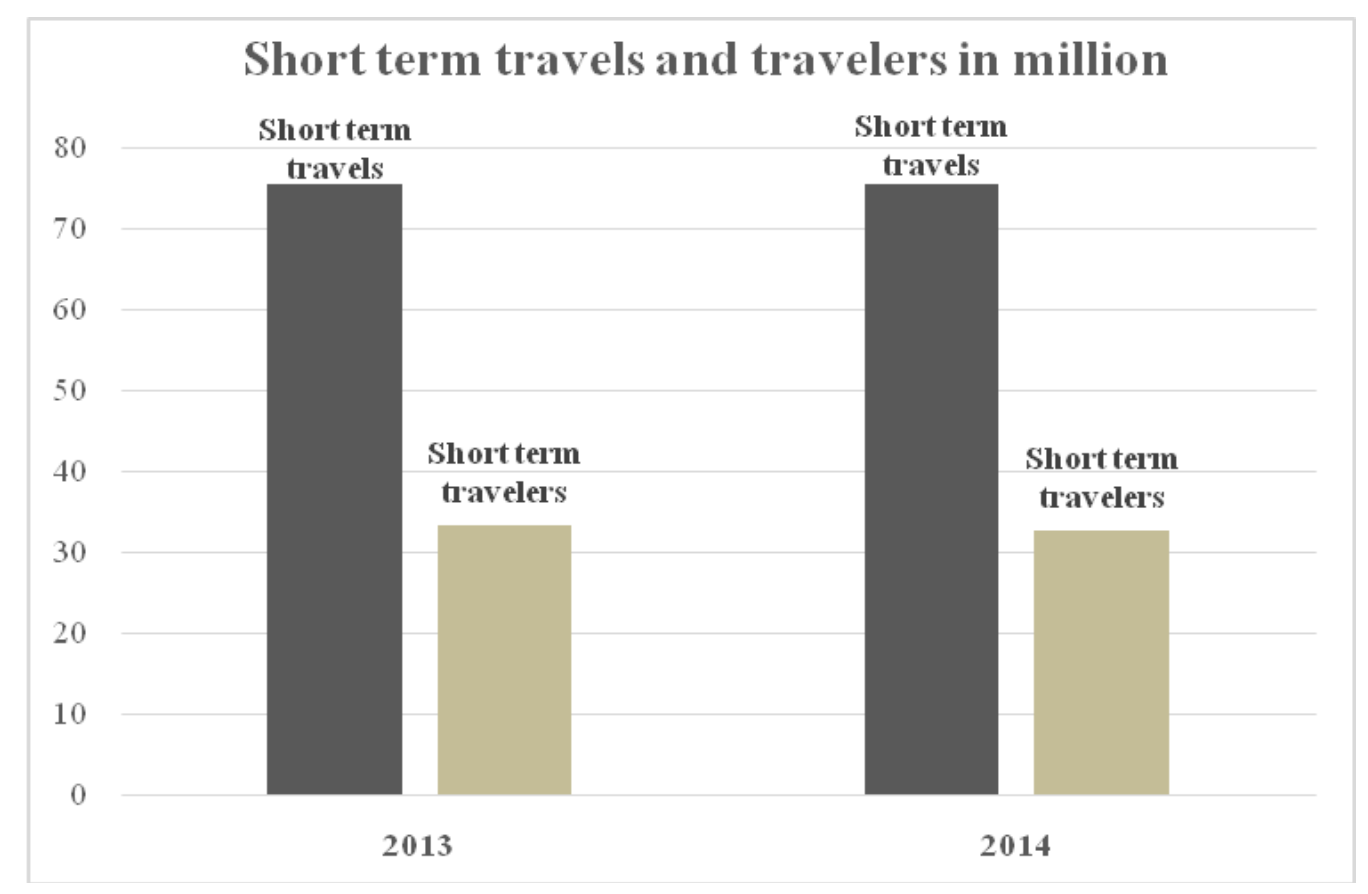

Fig. 2 Short-term travels and the number of travellers in million (Source: Forschungsgemeinschaft Urlaub und Reisen e.V., 2015)

The number of short-term holidays is stable and remains at a high level similar to the holiday travels. In 2014, 32.6 million short-term travellers went on 75.7 million short-term holidays. The travel frequency of short-term travels was 2.32 per person in 2014. (10)

In 2013 there were 33.3 million travellers who made 75.6 million short-term travels. (9)

\subsection{Purpose of travel}

According to the data obtained from the surveys, the most popular type of holidays for Germans are beach and bathing holidays (55\%). (10)

Latvia is rich in seacoasts and beaches and therefore offers the possibility to go on bathing holidays. The most famous seaside resort is Jurmala, located $25 \mathrm{~km}$ away from Riga. Nevertheless, despite having 
beautiful beaches and coasts, it cannot be considered a typical bathing destination. There is one fixed factor which makes this impossible: the climate. Due to its geographic location, Latvia has a cool moderate climate. The yearly average temperature is $6{ }^{\circ} \mathrm{C}$. The summers are moderate warm and the temperatures are around $17{ }^{\circ} \mathrm{C}$. Summer in Latvia lasts from June till September. It means that Latvia can satisfy customer needs and become a tourist destination considering the most popular motivation of Germans, namely, to go on bathing holidays, only to a certain degree. Consequently, one disadvantage of Latvia as a bathing destination is the seasonality and its climate. Moreover the German tourists who like to travel to the Baltic Sea also have the possibility to spend their holidays in their home country, in Germany. It requires fewer efforts, due to the language and the distance. Furthermore, Poland is another competitor with its significant advantages, i.e. shorter distance to the German source market and lower prices. (8)

Apart from other countries which border to the Baltic Sea, there are also various competitors in other areas; predominantly these are the countries around the Mediterranean Sea like Spain, France, Italy, Greece and Turkey. These countries have a greater advantage - the climate. Besides, German travel agencies offer a lot of cheap package holidays to these destinations.

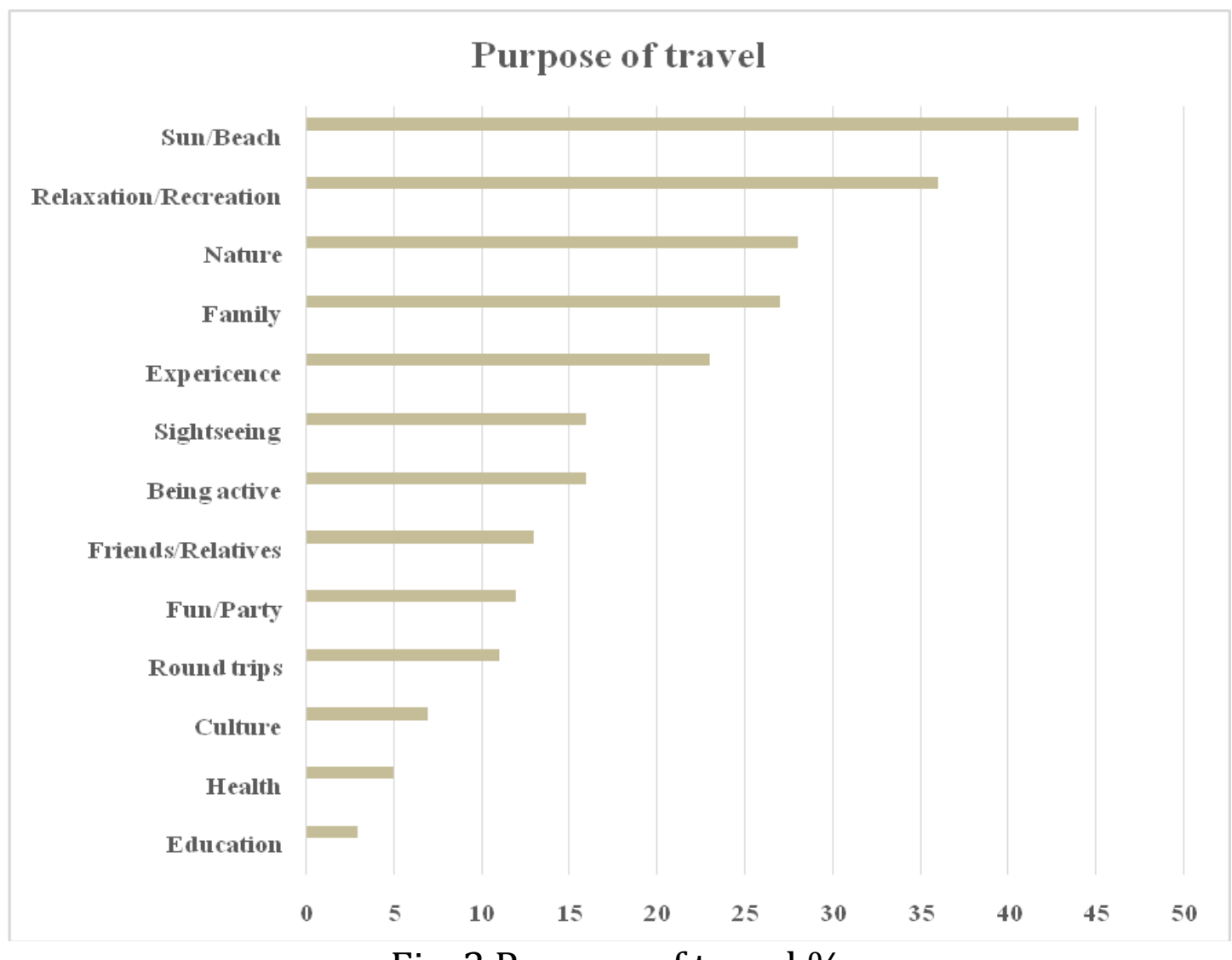

Fig. 3 Purpose of travel \%

(Source: Forschungsgemeinschaft Urlaub und Reisen e.V., 2015) 
More than $40 \%$ of the holiday travels are package tours or module travelling which are organized with the help of travel agencies or tourist offices. In Germany there are over 9,800 tourist offices and more than 2,500 travel agencies. This tourism infrastructure, mainly characterized by medium-sized suppliers and some big corporations, is unique to this world. (6)

For decades, the main motivating factors for German holiday travellers have been relaxation and recreation which appear to be the second important on the list of motivating factors for German travellers (36\%). In 2014 the majority reported that their holidays were satisfying. (10)

The third biggest motivation for going on holidays is experiencing the nature (28\%). (10)

In contrast to the bathing holiday, the conditions for relaxation, recreation and enjoying the nature in Latvia are better. In Latvia there are various spa and health resorts which have a wide range of offers, concentrating on wellness and spa services. The companies and hotels focused on spa and health are mainly located in the area around Riga, Jurmala, Liepaja and Ventspils. (12)

In Latvia there are four nature reserves, four national parks and 21 biosphere reserves. These reserves are characterized by their untouched nature and are protected by law. (15) The Latvian landscape is rather vivid; there is a long coast, a lot of forests and many lakes. In Latvia there are many different activities to enjoy the nature, such as walking through the woods, picking mushrooms or watching birds.

These travel motivations are dependent on the climate, similar to the bathing and beach holidays. In the summer season the needs of the German tourists are easier to satisfy. However, there are different possibilities to offer tourism products embracing also other seasons. For instance, Latvia is famous for its bathhouse culture as well as other wellness and spa services that can be offered all the year round.

Especially winter can be a highlight for tourists who are interested in the nature.

For the purpose of sightseeing, Riga plays the most important role in the Latvian tourism market. Riga, with more than 700,000 inhabitants, is the biggest city in the Baltic States and a UNESCO world heritage as well. Riga combines various types of tourism, such as culture, architecture, gastronomy, recreation and relaxation, wellness and beauty, shopping, and health. Especially regarding the short-term travels Riga satisfies the needs of a tourism destination. (17)

People who want to do a round trip can do it in Latvia, visiting different cities and enjoying landscapes. However, Latvia is more suitable 
as a tourism destination integrated in an international round trip. For instance, it can be integrated into a round trip through the Baltic States or visiting Riga as a part of a cruise in the Baltic Sea.

Latvia has a colourful past and its culture faced intense influence if we are looking back on the historical aspects. Therefore it can be stated that the Latvian culture is abundant and diverse and is suitable for the German tourists who are interested in history and culture. Latvia is also rich in art and music; there are different operas, theatres and music festivals. Additionally Latvia offers cultural activities such as handicraft or cookery courses for traditional Latvian food. (14)

Another fact about German travellers that has a certain degree of importance for the Latvian tourism industry is health and medical tourism. For a lot of Germans, medical treatment in foreign countries is a real alternative to the medical treatment in Germany. Latvia offers medical and health services at a lower price and ensures nearly the same quality as western countries do. (3) (20)

Latvia offers various healthcare treatment programmes and services such as rehabilitation, dental care, eye care or plastic and reconstructive surgery. (13)

The motivation of getting new experience and being active are combined with other types of travel. For example, you can be active during your summer holidays and do different types of water sports. Or combine your holiday in the nature with winter sport activities or a culture trip with handicraft.

A change in the motivations may be expected in the long-term. The reasons for going on holidays will vary. For instance, relaxation, action and culture are not the only motivating factors to initiate holidays. These motivations will be combined. The holidays should be exciting and at the same time should have elements of relaxation and recreation.

Consequently, the holiday types that are possible to combine prevail and have the highest growth potential. (10)

\subsection{Most popular Destinations}

Germany with a market share of $31 \%$ was the most popular destination of the German population. 7.6\% of the holidays are longdistance journeys. The rest of the holidays are short-distance and medium-distance journeys. (21)

The most popular states in Germany are Mecklenburg-Western Pomerania (6\%), Bavaria (5.9\%), Schleswig-Holstein (4.2\%) and Lower Saxony (4.0\%).

It is noticeable that three out of the four most popular destinations in Germany are the states with coasts and islands. For the German 
outgoing tourism, the destinations of the Mediterranean Sea are highly appreciated.

Table 1 The most popular destinations for holiday travels (Source: Stiftung für Zukunftsfragen, 2015)

\begin{tabular}{|l|l|l|l|l|}
\hline No & $\begin{array}{l}\text { Destinations } \\
\text { in Germany }\end{array}$ & $\begin{array}{l}\text { Destinations in } \\
\text { Germany,\% }\end{array}$ & $\begin{array}{l}\text { Foreign } \\
\text { Destinations }\end{array}$ & $\begin{array}{l}\text { Foreign } \\
\text { Destinations, \% }\end{array}$ \\
\hline 1. & $\begin{array}{l}\text { Mecklenburg- } \\
\text { Western Pomerania }\end{array}$ & 6.0 & Spain & 13.5 \\
\hline 2. & Bavaria & 5,9 & Italy & 7.8 \\
\hline 3. & Schleswig-Holstein & 4.2 & Turkey & 7.0 \\
\hline 4. & Lower Saxony & 4.0 & Austria & 4.9 \\
\hline
\end{tabular}

The Mediterranean Sea has a market share of 36.2\%. Western Europe follows with $13.3 \%$ and East Europe with $6.6 \%$. The three most popular destinations in foreign countries are located at the Mediterranean Sea. They are Spain (13.5\%), Italy (7.8\%) and Turkey (7.0\%). Austria with a market share of $4.9 \%$ is the fourth most popular destination (21) (see Table 1).

Regarding the short-term holidays, the travels in Germany have a bigger market share, $76 \%$ which are 54.7 million. $35 \%$ of these travels are city tours. 24\%, 17.5 million, of the short-term holidays were the destinations in foreign countries. 9\% of these were city tours. (21) The most popular destinations within Germany (see Table 2) are Bavaria (12.4\%), Berlin (7.8\%) and North Rhine-Westphalia (7.7\%).

The most important foreign targets were Austria (3.6\%), France (3.0\%) and the Netherlands $(2.8 \%)$. Due to the distance, the most popular foreign destinations are Germany's neighbouring countries. (21)

Table 2 The most popular destinations for short-term travels (Source: Stiftung für Zukunftsfragen, 2015)

\begin{tabular}{|l|l|l|l|l|}
\hline No & $\begin{array}{l}\text { Destinations } \\
\text { in Germany }\end{array}$ & $\begin{array}{l}\text { Destinations in } \\
\text { Germany,\% }\end{array}$ & $\begin{array}{l}\text { Foreign } \\
\text { Destinations }\end{array}$ & $\begin{array}{l}\text { Foreign } \\
\text { Destinations, \% }\end{array}$ \\
\hline 1. & Bavaria & 12.4 & Austria & 13.5 \\
\hline 2. & Berlin & 7.8 & France & 3.0 \\
\hline 3. & $\begin{array}{l}\text { North Rhine- } \\
\text { Westphalia }\end{array}$ & 7.7 & Netherlands & 2.8 \\
\hline
\end{tabular}

City tours play an important role in the segment of short-term holidays. The most visited city in Germany was Berlin with the market share comprising $7.8 \%$ of all short-term holidays. Hamburg (5.5\%) and Munich (3.4\%) follow (see Table 3). 
In foreign countries the most popular cities were London $(1.5 \%)$, Paris (1.1\%) and Amsterdam (0.9\%). (21)

Table 3 The most popular destinations for city trips (Source: Stiftung für Zukunftsfragen, 2015)

\begin{tabular}{|l|l|l|l|l|}
\hline No & Cities in Germany & $\begin{array}{l}\text { Cities in } \\
\text { Germany,\% }\end{array}$ & Foreign cities & Foreign cities, \% \\
\hline 1. & Berlin & 7.8 & London & 1.5 \\
\hline 2. & Hamburg & 5.5 & Paris & 1.1 \\
\hline 3. & Munich & 3.4 & Amsterdam & 0.9 \\
\hline
\end{tabular}

Latvia is a part of the third biggest destination group of the German tourists, of Eastern Europe, where 6.6\% spent their holidays. First one might think that this figure is really low but in absolute numbers $6.6 \%$ means around 4.6 million, which is more than twice than the population of Latvia and the short-term travels are not included in this number. Accordingly, it means that the German tourism market has a high potential market for the Latvian inbound tourism. In 2013, Germans were the fifth biggest tourism group (123.4 thousand) after Russia (332.6 thousand), Lithuania (209.5 thousand), Sweden (194.7 thousand) and Estonia (146.1 thousand). (5)

Another indicator of the importance of the German outbound tourism for Latvia is "The Latvian Tourism Marketing Strategy 20102015". Germany was categorized as a high priority market in this strategy. (11)

\subsection{Expenditures}

In 2014 expenditures on holiday travels reached their overall peak. Compared with 2013, the expenditures increased by about 5\% up to EUR 67.3 billion. In addition to that there are EUR 19.8 billion of expenditures referred to the short-term holidays. (10)

Expenditures per person and per travel were EUR 958 regarding holiday travels and EUR 261 as regards to the short-term travels. The numbers of travellers who are willing to spend a big amount of money is increasing. The high price segment which means that expenditure per person is more than EUR 3,000 got doubled in the last ten years. In 2014, 2.4 million people spent more than EUR 3,000 on their holidays which constituted $3 \%$ of all holiday travellers. The high price segment has a high share in regards to all expenditures, 14\%, which are EUR 9.5 billion. (10) The price level in Latvia is lower than in Germany. Especially when it comes to services like restaurants or taxis one can feel the price differences. Due to the fact that services play an important role in the 
tourism industry, this price difference can be considered an advantage for Latvia. However, it should be considered that compared to Germany a lot of countries have a lower price level, also the countries that are direct competitors for the German tourists. (8)

\subsection{Transportation}

The plane as a kind of transport is increasing its market share. However, with $46 \%$ the car remains the most used kind of transport for travels. It is followed by the plane (39\%), the bus (8\%) and the train (5\%). (10)

In 2014 the number of passengers at all German airports were around 208 million. This amounted to 6.1 million or 3\% passengers more than in 2013. 208 million passengers can be divided into flights within Germany (45 million passengers), flights throughout Europe (125 million passengers) and in intercontinental flights (38 million passengers). (21)

The airports receiving the highest number of passengers in Germany (see Table 4) are Frankfurt/Main with around 60 million and Munich with around 40 million passengers. 28 million passengers in Berlin are divided into Tegel (20.7 million) and Schönefeld (7.3 million). (21)

The trains in Germany transported 2.7 billion passengers in 2014.

3,900 bus companies existed in Germany in 2012. They transported 79 million passengers and travelled 20.8 billion passenger kilometres. The top travel destinations of passengers who took the bus as a kind of transport in 2013 in Germany were Bavaria (7.6\%), Mecklenburg Western-Pomerania (4.5\%) and Lower Saxony (3.6\%). The most popular targets in Europe were Italy (10.9\%), Austria (10.9\%) and Poland (7.0\%). (21)

Table 4 The biggest airports in Germany

(Source: Forschungsgemeinschaft Urlaub und Reisen e.V., 2015)

\begin{tabular}{|c|c|c|}
\hline No & Name of airport & Number of passengers, million \\
\hline 1. & Frankfurt/Main & 60 \\
\hline 2. & Munich & 40 \\
\hline 3. & \begin{tabular}{ll}
\multicolumn{2}{l}{ Berlin } \\
- & Tegel \\
- & Schönefeld
\end{tabular} & $\begin{array}{ll}28 & \\
- & 20.7 \\
- & 7.3\end{array}$ \\
\hline
\end{tabular}

In 2014 the cruise market had a turnover of EUR 2.7 billion and 1.77 million passengers. The most popular destinations for sea cruises were the Mediterranean Sea/Black Sea, the United Kingdom/Western Europe, Northland, the Atlantic and the Canary Islands. Tours on the Danube and 
Rhine rivers are the most popular river cruises. The turnover in 2014 was EUR 396 million generated by 416 thousand passengers. (21)

The most used kind of transport to go on holidays is the car. It takes around 16 hours $(1200 \mathrm{~km})$ from Berlin to Riga by car and about 18 hours from Frankfurt/Main $(1730 \mathrm{~km})$ and Munich $(1770 \mathrm{~km})$. For most the people a nonstop travel by car from Germany to Latvia would be too long, however, it is possible. If you split the travel and spend some nights, for instance, in the Czech Republic, in Poland or in Lithuania the distances are quite comfortable.

The most suitable way to get from Germany to Latvia is by plane. A flight from Germany to Riga lasts for about two hours. The Riga Airport is the biggest one in the Baltic States. It offers good flight connections to various German airports. (2)

Furthermore, the ticket prices are quite low because of a large number of offers and the fact that low cost carriers like Ryanair operate flights from Riga to Germany. Ryanair offers flights from Riga to Berlin, Bremen, Cologne, Düsseldorf and Frankfurt/Hahn. (19)

The advantage of using the bus as a kind of transport is that there are more departure and arrival possibilities in Germany and in Latvia. It is possible from nearly every bigger city in Germany to travel to Latvia. However, the duration is longer than by car. A direct connection between Berlin and Riga requires around 20 hours. And the price level is the same as flying by plane. (7)

Overall travelling by plane is the best transportation for German travellers to the tourism destination - Latvia. Flights are frequently available, there are connections from many different airports in Germany to Riga, the duration of a flight is around two hours and the prices are low.

\subsection{Duration of visit and type of accommodation}

The average duration of the travel holidays was 12.5 days. Compared to the previous year 2013, with 12.4 days there were no noticeable changes. The average duration of holidays within Germany is shorter than border crossing holidays. Within the German border the average period is 10.3 days and in foreign countries 13.5 days. (10)

The predominant types of accommodation used are a hotel and a guest house with $46 \%$ market share. Holiday flats and houses are used by $24 \%$ of the population and are the most used types of accommodation within Germany. Only 6\% of the population choose camping holidays. (10) 


\subsection{Expectations for 2015}

The expectations for the German outbound tourism in 2015 are positive. $55 \%$ of the population already planned their holidays and only $11 \%$ are sure they will not travel in 2015.

The expenditures will be more or less the same as in $2014.12 \%$ plan with higher expectations and 9\% want to spend less than in the previous year. An important indicator for the travel plans is personal evaluation of the economic situation. The German population is optimistic about their economic situation, $18 \%$ think their economic situation will be better in $2015,10 \%$ expect a worse situation. The biggest part of the population doesn't expect any changes in their economic situation. (10)

In the travel planning for 2015 Germany is, with 35\%, the most popular destination. The most popular foreign destination for the next year will be Spain and Italy with around 13\%. 6\% want to spend their holidays in Eastern Europe. (1)

\subsection{Holiday trends}

In Germany tourism is a sector with a bright future. The demand will be more or less stable remaining at a high level. This makes planning for the travel and tourism industry possible. However, changes in the structure of the demand are expected.

Due to the demographic change, society in Germany is getting older and migration makes the society more diverse.

Compared to the last year, travel frequency remained even. Nevertheless compared with the last years, a rising trend can be traced. Accordingly the number of travellers in Germany increased from 50\% in 2009 to $54 \%$ in 2012 and $57 \%$ in 2014 . This trend shows that the majority of Germans are fascinated by travelling and the travel boom will continue in the future. (10)

Another noticeable trend is a more extensive use of the internet. It is not only used for planning and preparing a holiday, it is also important for booking the accommodations and transportation.

\section{Main Target groups}

\subsection{Social Experiencer}

A "Social Experiencer" is one of the two main target groups for inbound tourism in Latvia. This group encompasses the generation of 5575 years. The Social Experiencer travels in couples or in small groups. This kind of a traveller is a loyal one, focused on the sustainable tourism. Furthermore such "social experiencers" prefer earthbound travel. The interactive experience and the social aspects are of high significance for 
the Social Experiencer. This kind is characterized by a high degree of involvement before, during and after the travel as well as by openness to experience, countries and people.

The Social Experiencer expects an authentic infrastructure, with the main focus on nature experiences and the feeling of the local and rustic atmosphere, striving to taste regional food, meet people and spend time with others. (4)

\subsection{Conscious Discoverer}

The other big target group for inbound tourism is the group of a "Conscious Discoverer". The typical conscious discoverer is fifty or more years old and travels as a couple or single without children. This kind of a traveller wants to experience culture and explore the new world, prefers round trips and modular packages, and likes to travel from destination to destination. The security and control plays an important role for the conscious discoverer. The main focus on what the one wants to experience is placed on culture and history. Comfortable accommodation in the category of four stars is expected. The travel should be perfect and professionally organized emphasising the presence of the information in the German language. (4)

\section{Conclusions}

The German outbound tourism has a high potential for the tourism industry in Latvia. Tourists from Germany comprise one of the biggest incoming segments for Latvia. Therefore the German source market is of high priority for the Latvian tourism industry.

Latvia has its strengths in the holiday types such as relaxation and recreation, nature and culture. These types should be combined with the opportunity to gain experience and be active. Furthermore, Riga has a great potential as a destination for city trips. Another type of tourism which is important for the Latvian tourism industry to satisfy the needs of the German tourists is health and medical tourism.

Due to the fact that the German society is getting older and that the two main target groups for the Latvian incoming tourism are travellers aged 50 and older and the main focus of the Latvian tourist industry should be placed on these particular segments.

An example of a good tourism product would be a round trip round Latvia by bus. The arrival could be from different German cities to Riga by plane. The round trip starts and ends in Riga and the travel encompasses different places in Latvia for around 10 days. The main focus should be placed on history, culture and nature. The travel has to be organized by a professional tour guide who gives guided tours and 
information 24 hours a day in the German language. This would make the German tourists feel safe and secure. The overnight stays should be in a four-star type of accommodation.

This round trip can be combined with the visit to other Baltic States. Thus the source market would be bigger because the tourist offer would be broader and accordingly would satisfy the needs of German travellers to a higher degree. A round trip could satisfy the motivation to enjoy relaxation, nature, culture, history, experience, the possibility to be active and a city tour at the same time. Consequently, a perfect tourism product would be a combination of these factors. Latvia is not a typical tourism country as, for instance, Spain or France. Therefore it has to be admitted that Latvia should use this as an advantage as long as it offers an authentic experience with abundant nature and culture and the tourist attractions are not overcrowded by millions of tourists and it is possible to feel the real Latvian life.

\section{References}

1. ADAC Verlag Studie. (2015). Trendforschung im Reisemarkt 2015. p.6. Retrieved March 12, 2015 from http://media.adac.de/mediaservice/ studien.html

2. Billigflieger.de. (2015). billigflieger.de. Retrieved March 29, 2015 from http://www.billigflieger.de/suchergebnis

3. Bongartz, U. (2012). Lettische Presseschau: Lettland: Staatliche Agentur fördert Medizintourismus. Retrieved March 28, 2015 from http://www.lettischepresseschau.de/projekte/13-projekte/597-lettland-staatliche-agentur-foerdertmedizintourismus

4. Buergdorff, M. (2009). Perspective German market Baltikum-Tourismus-Zentrale. Retrieved February 20, 2015 from http://www.tava.gov.lv/sites/tava.gov.lv/ files/dokumenti/prezentacijas/turisma-forums-2009/11-Vacijas-tirgusM.Burgdorff.pdf

5. Central Statistical Bureau of Latvia. (2015). OVERNIGHT NON-RESIDENT TRAVELLERS BY THE COUNTRY OF RESIDENCE (thousands). Retrieved March 20, 2015 from http://data.csb.gov.lv/pxweb/en/transp/transp_ikgad_turisms/ TU0041.px/table/tableViewLayout1/?rxid=a79839fe-11ba-4ecd-8cc3$4035692 \mathrm{c} 5 \mathrm{fc} 8$

6. Deutscher Reiseverband . (2015, February). Fakten und Zahlen 2014 . p.4

7. Ecolines. (2015). ecolines.net. Retrieved March 28, 2015 from http://legacy.ecolines.net/index.php?s=718\&_utma=245410960.784799558.1 426608048.1427678937.1427685811.8\&_utmb $=245410960.4 .8 .1427685827$ 855\&_utmc $=245410960 \& \_u t m x=\& \_u t m z=245410960.1427685811 .8 .7 . u t m g c$ lid=CJyxkIyQz8QCFebHtAodp2YAOQ|utmccn=\%28not $\% 20$ set $\% 2$

8. Eurostat. (2014). Vergleichende Preisniveaus. Retrieved March 3, 2015 from http://ec.europa.eu/eurostat/tgm/table.do?tab=table\&plugin=1\&language=de \&pcode=tec 00120

9. Forschungsgemeinschaft Urlaub und Reisen e.V. (2014). Reiseanalyse 2014 Erste Ausgewählte Ergebnisse. Retrieved February 15, 2015 from 
http://www.fur.de/fileadmin/user_upload/RA_Zentrale_Ergebnisse/RA2014_E rsteErgebnisse_D.

10. Forschungsgemeinschaftt Urlaub und Reisen e.V. (2015). Reiseanalyse 2015 Erste Ausgewählte Ergebnisse. p.2, p.4, p.6. Retrieved February 15, 2015 from http://www.fur.de/fileadmin/user_upload/RA_2015/RA2015_Erste_Ergebniss e_DE.pdf

11. Latvian Tourism Marketing Strategy2010-2015. Retrieved March 5, 2015 from www.TAVA.gov.lv

12. Lettisches Fremdenverkehrsamt. (2015). Spa. Retrieved March 18, 2015 from http://www.latvia.travel/de/artikel/spa

13. Lettisches Fremdenverkehrsamt. (2015). Medizintourismus. Retrieved March 28, 2015 from http://www.latvia.travel/de/artikel/medizintourismus

14. Lettisches Fremdenverkehrsamt. (2015). Geschichte und Kultur. Retrieved March 21, 2015 from http://www.latvia.travel/de/artikel/geschichte-undkultur

15. Lettisches Fremdenverkehrsamt. (2015). Nationalparks und Reservate. Retrieved March 15, 2015 from http://www.latvia.travel/de/artikel/ nationalparks-und-reservate

16. Lettisches Fremdenverkersamt. (2015). Unsere Werte und Besonderheiten. Retrieved March 12, 2015 from http://www.latvia.travel/de/artikel/unserewerte-und-besonderheiten

17. Lettisches Fremdenverkehrsamt. (2015). Riga. Retrieved March 12, 2015 from http://www.latvia.travel/de/city/riga-8

18. Lettisches Fremdenverkersamt. (2015). Das Wetter in Lettland. Retrieved March 30, 2015 from http://www.latvia.travel/de/artikel/das-wetter-lettland

19. Ryanair. (2015). Access: http://www.ryanair.com/ ,retrieved March 29, 2015

20. Schmidt, L. (2013). Frankfurter Allgemeine: Wir gehen für die Therapie ins Ausland. d March 28, 2015 from http://www.faz.net/aktuell/wissen/medizin/ medizintourismus-wir-gehen-fuer-die-therapie-ins-ausland-12011230.html

21. Stiftung für Zukunftsfragen. (2015). Tourismus Analyse 2015. p.4, p.6, p.7, p.14, p.16, p.17, p.18 Retrieved March 29, 2015 from http://www.tourismusanalyse.de/de.html

\section{LATVIJA KĀ VĀCU CEḶOTĀJU TŪRISMA GALAMĒRḲIS}

\section{Benjamin BLATT}

Vormsas Lietiškso zinātṇu universitāte, Wormsa, Vācija

\section{Kopsavilkums}

Latvija ir unikāla tūrisma valsts, bagāta ar saviem dabas un kultūras resursiem, tās ǵeogrāfiskais stāvoklis rada lieliskas ceḷošanas iespējas rietumu valstu, t.sk. vācu tūristiem. Daudzās vietās Latvijā ir saglabājusies neskarta daba, Tas, savukārt, ḷāva attīstīt tādus tūrisma veidus, kā atpūtas, relaksācijas, veselības, ūdens tūrismu u.c.

Bagātīgie kultūrvēsturiskie resursi, atšksirīgās tradīcijas, multikulturālā vide, daudzveidīgā sakrālā kultūra, medicīnas un veselības tūrisms pievilina daudzus ārzemju tūristus. Vācu tūristu skaits Latvijā ar katru gadu pieaug. Šì pētījuma mērḳis ir izanalizēt Latvijas tūrisma piedāvājuma iespējas, kas varētu veicināt vācu tūrisma 
plūsmu Latvijas virzienā. Pētījumā tiek analizēts izejošais vācu tūrisms pēc tādiem parametriem, kā brīvdienu cel̦ojumi, populārākie cel̦ojumu galamērḳi, cel̦ojuma motivācija, izdevumi, ceḷojuma ilgums u.c. Tāpat pētījumā tiek analizētas tūrisma tendences Vācijā. Autors piel̦auj, ka galvenā tūristu mērḳgrupa no Vācijas ir vecumā virs 50 gadiem, kas ir ieinteresēta veselības un medicīnas tūrismā Latvijā. Izvirzītā hipotēze, ka Latvija ir pievilcīgs tūrisma galamērḳis vācu tūristiem, ir apstiprinājusies.

Atslēgas vārdi: tūrisma attīstība, tūristu uzvedība. 